\title{
Carbon Sequestration and Growth of Stands of Cassia siamea Lamk. in Coal Mining Reforestation Area
}

\author{
Sadelillyas* \\ Faculty of Forestry, Mulawarman University, Samarinda, East Kalimantan, Indonesia; sadeli.ilyas@yahoo.com
}

\begin{abstract}
Allometric equations resulting from the relationship between the diameter breast height and stem volume for Cassia siamea Lamk. stand in the coal mining reclamation / reforestation area is $\mathrm{Y}=0.00013 \mathrm{X}^{2.36351}$ with $\mathrm{R}^{2}=0.96370$. The relationship between diameter at breast height (DBH) with tree biomass for $C$. siamea where allometric equation for stem is $\mathrm{Y}=0.3699 \mathrm{X}^{1.9374}$ with $\mathrm{R}^{2}=0.9869$, for the branch is $\mathrm{Y}=0.1782 \mathrm{X}^{1.7148}$ with $\mathrm{R}^{2}=0.9547$ and for the leaves is $\mathrm{Y}=0.1651 \mathrm{X}^{1.5272}$ with $\mathrm{R}^{2}=0.9469$.
\end{abstract}

Keywords: Reforestation, Coal Mining, Carbon Sequestration, Allometric Equation, Carbon Sink.

\section{Introduction}

Global warming the major concern for all the countries in the world. It is mainly related to increase in the temperature of earth due to the burning of fossils fuels. Climatic changes occur due to changes in the carbon dioxide levels in the atmosphere i.e. more carbon dioxide accumulation in the atmospheres [1].

Carbon dioxide $\left(\mathrm{CO}_{2}\right)$ is the primary greenhouse gas emitted through human activities. In 2011, $\mathrm{CO}_{2}$ accounted for about $84 \%$ of all U.S. greenhouse gas emissions from human activities [2]. Carbon dioxide is one of the greenhouse gases contributing to global warming and subject to the Kyoto Protocol. Carbon emissions from deforestation, the burning of fossil fuels, changes in land use, and other human activities are increasing, while the earth's ability to soak up, or fix the carbon, is decreasing because of ocean and forest changes. Reforestation is a way to help restore the balance. Planting trees, especially quick-growing native trees that will not be logged or burned, remove carbon from the cycle and sequesters, or fixes it within the wood itself [3].

Forests are an important part of the global carbon cycle because trees and plants absorb carbon dioxide through photosynthesis. By removing this greenhouse gas from the air, forests function as terrestrial carbon sinks, meaning they store large amounts of carbon. At any time, forests account for as much as double the amount of carbon in the atmosphere [4]. Reforestation is the process in which forests are renewed after they have been harvested. The renewal process is done either by natural regeneration, planting new trees or by a combination of both methods [5]. There are a number of benefits to reforestation and sustaining forests is worthwhile for anyone concerned with environmental issues. As more and more people begin to be concerned about the environment, many look into ways that they can contribute on a local level. There are many programs that are available for citizens to be part of this global issue [5]. Sennasiamea Lamk. (synonyms: Cassia siamea Lamk., C. florida Vahl.; Sennasumatrana,

*Corresponding author:

Sadelillyas (sadeli.ilyas@yahoo.com) 
Roxb.) is a nonnitrogen-fixing leguminous tree in the subfamily Caesalpinoideae of the family Leguminosae [6]. Sennasiamea also known as Kassod Tree, Cassod Tree and as Cassia tree $[7,8]$. It is native to South and Southeast Asia, although its exact origin is unknown.[9]. Used extensively for rehabilitation of degraded land, for example, to revegetate aluminium mine tailings. Soil improver: Leaves are used as green manure, and a well-grown tree can yield $500 \mathrm{~kg} /$ year of fresh leaves. C. siamea forms ectomycorrhizae and provides very useful mulch, especially in alley-cropping systems [9]. It has been widely planted in many Southeast Asian countries for erosion control, windbreaks, shelterbelts, fuelwood, and polewood. It is a good ornamental tree for planting along roadsides, and it is also used in alley cropping, intercropping, and hedgerows. It is planted as a shade tree in cocoa, coffee, and tea plantations [10].

The objectives of this study were to compare growth characteristics and biomass accumulations of $C$. siamea obtained from two different sites and to evaluate the possibility of formulating a single allometric equation, and to estimate optimum rotation of C. siamea plantations in East Kalimantan, Indonesia.

\section{Material and Methods}

\subsection{Study Sites}

The experiment wereconducted from March 2009 to October 2009 in C. siamea plantations in coal mining area of MSA Coal Mining Company, East Kalimantan, Indonesia. Field of experiment were conducted in four plots of C. siamea plantation sites with stand ages of 7, 5, and 3 years (One plot in not mined areas and three plots in mined areas).

The area is locate at longitude $117^{\circ} .03^{\prime} 55^{\prime \prime}$ East and latitude $0^{\circ} .37^{\prime} 30^{\prime \prime}$ South and at elevation $40-50 \mathrm{~m}$ above sea level, the annual temperature range between $20^{\circ} \mathrm{C}$ $33^{\circ} \mathrm{C}$ and annual rainfall is about $2.000 \mathrm{~mm}$. [11].

\subsection{Plot Setting}

Three plots $(20 \times 30 \mathrm{~m})$ for each stand age were established for evaluate tree growth and to estimate biomass. Stem diameter at breast height (D; $1.3 \mathrm{~m}$ above ground) and tree height $(\mathrm{H})$ were measured for all $C$. siamea trees in the plot. D was measured using tape. $\mathrm{H}$ was measured usingsuunto clino-meter.

\subsection{Estimation of Tree Biomass}

The tree biomass can be expressed as the average mass per unit area, or as the total mass in the community [12]. To formulate allometric equations for trees, about 10 different D-sized (trees $>2 \mathrm{~cm}$ in diameter) trees were cut down around the plots. This study was carried out through the destructive sampling technique of plant age on the level of Cassia siamea 3, 5 and 7 years old. To estimate the biomass of forest plants, carried out measurements of diameter and height on the whole plant in an area of 0.06 ha $(20 \times 30$ $\mathrm{m})$ are repeated as many as three times. To build the equation allometri, at any grade of logging is done to the age of 12 trees which represents the distribution of diameter. In addition to the quantity of tree diameter and height, diameter and weight measurement carried out each of logs, branches and twigs, leaves and roots. To find out, the biomass of individual plant parts taken samples of about 250 grams of dried and based on the ratio of wet weight and dry weight, the biomass per tree, part of the stem, branches and twigs, leaves and total biomass can be calculated. Biomass per plot is the sum of each individual tree biomass contained in swaths of the study concerned, and through the conversion of land coverage area, hence the accumulation of biomass or carbon content per hectare can be known.

\section{Results and Discussion}

\subsection{Growth of Stand C. siamea}

Establishing vegetation is an important activity in reclaiming mined lands. Revegetation encourages minesoil development, creates an aesthetically pleasing landscape, and contributes to productive postmining land use. Prompt and thorough establishment of vegetation after mining is essential to comply by coal-mining operations [13].

There are two typical stand structures even-aged and uneven-aged in silvicultural systems. An even-aged stand is a group of trees composed of a single age class, and thus originated within a short period of time. Diameters at Breast Height (DBH) in an even-aged stand show some variation, although most trees cluster near the average diameter, with decreasing frequencies at large and small diameters [14].

Result of investigation on growth and development of stands C. siamea in each stand age class 3, 5 and 7 years in mined areas and areas not mined are listed in Table 1 [15].

There is a difference between standing on the areas non mined by the mined. From the data obtained shows 
Table 1. Growth of Stand C. siamea on mined areas and not mined areas

\begin{tabular}{cccccc}
\hline $\begin{array}{c}\text { Stand } \\
\text { age } \\
\text { (year) }\end{array}$ & $\begin{array}{c}\text { Mean } \\
\text { Diameter } \\
(\mathrm{cm})\end{array}$ & $\begin{array}{c}\text { Mean } \\
\text { Height } \\
(\mathrm{m})\end{array}$ & $\begin{array}{c}\text { Volume } \\
\mathbf{h a}^{-1} \\
\left(\mathbf{m}^{-3}\right)\end{array}$ & $\begin{array}{c}\text { Bassal } \\
\text { Area } \\
\mathbf{h a}^{-1} \\
\left(\mathbf{m}^{-2}\right)\end{array}$ & $\begin{array}{c}\text { MAI } \\
\left(\mathbf{m}^{3}\right)\end{array}$ \\
\hline $7^{*}$ & 28.65 & 7.5 & 172.36 & 28.85 & 26.62 \\
$7^{* *}$ & 25.52 & 6.5 & 107.28 & 20.80 & 15.33 \\
$5^{* *}$ & 20.59 & 5.5 & 82.21 & 16.99 & 16.44 \\
$3^{* *}$ & 17.67 & 5.0 & 49.50 & 12.06 & 16.50 \\
\hline
\end{tabular}

MAI $=$ Mean Annual Icrement $; *$ not mined $; * *$ mined

that the volume per hectare in age 7 years, the area was non mined $172.36 \mathrm{~m}^{3}$ whereas the former mining areas only $107.28 \mathrm{~m}^{3}$. If calculated MAI in areas not mined is $26.62 \mathrm{~m}^{3}$ while the MAI for mined areas is $15.33 \mathrm{~m}^{3}$. Volume per hectare or MAI in not mined areas much bigger than the mined areas. This occurs because the soil conditions at the mined area has changed, which mined areas of land already degraded [15].

\subsection{Allometric Equation}

The above-ground biomass (AGB) of tropical forests is a crucial variable for ecologists, biogeochemists, foresters and policymakers. Tree inventories are an efficient way of assessing forest carbon stocks and emissions to the atmosphere during deforestation [16]. Allometric equations resulting from the relationship between the diameter breast heigh and stem volume for C. siamea stands presented in Figure 1. The Figure 1. is a graphic illustration of the allometric equation $\mathrm{Y}=0.00013 \mathrm{X}^{2.36351}$ with $\mathrm{R}^{2}=$ 0.96370 , which is the relationship between tree diameter at breast height of C. siamea by volume[15].

\subsection{Biomass in Revegetation Area}

Furthermore, Figure 2 shows the relationship between $\mathrm{DBH}$ with tree biomass for C. siamea where allometric equation for stem is $\mathrm{Y}=0.3699 \mathrm{X}^{1.9374}$ with $\mathrm{R}^{2}=0.9869$, for the branch is $\mathrm{Y}=0.1782 \mathrm{X}^{1.7148}$ with $\mathrm{R}^{2}=0.9547$ and for the leaves is $\mathrm{Y}=0.1651 \mathrm{X}^{1.5272}$ with $\mathrm{R}^{2}=0.9469$. When you see its $R^{2}$ value, then there is a close relationship between the $\mathrm{DBH}$ with biomass where the value is more than $90 \%$. [15].

Percentage of all tree components of biomass that stems, of branches and leaves are very variable, the percentage of

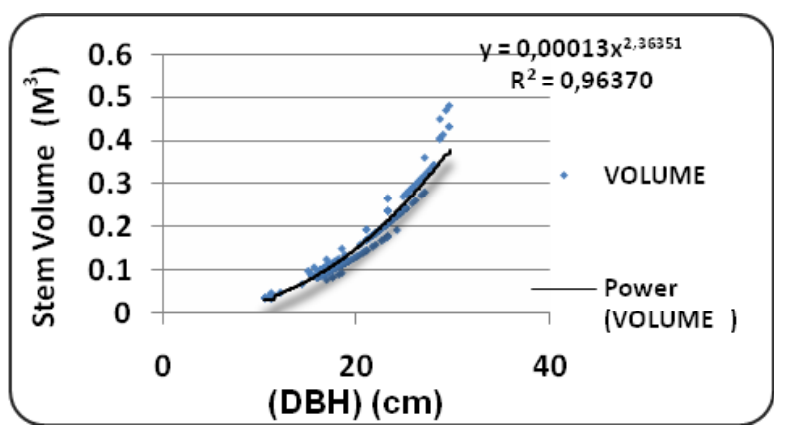

Figure 1. Allometricequation the relationship between volume and DBH stand of C. siamea.

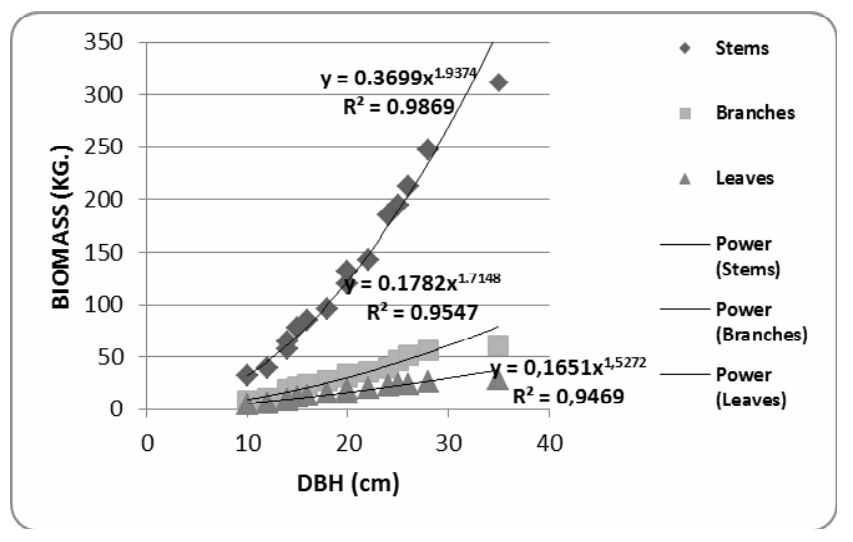

Figure 2. Allometric equation relationship between biomass and DBHstand of C. siamea.

stems biomass was $71 \%$, branches biomass was $20 \%$, and leaf biomass was 9\%. (Figure 3) [15].

Table 2. It appears that biomass is not mined areas showed a higher biomass than biomass in mined areas. At seven years of total biomass was $136.39 \mathrm{mg} \mathrm{ha}^{-1}$, while in the mined areas of the same age was $108.56 \mathrm{mg} \mathrm{ha}^{-1}$. This indicates that the biomass at mined area apparently around $70 \%$ lower than the biomass in areas not mined [15].

\subsection{Root Biomass}

There is increased interest in estimating the biomass of forests because of their role in regulating the cycling of carbon and nutrients. There are a variety of established methods for estimating the biomass in above ground tree components, but biomass of root systems is difficult to measure in any forest ecosystem [17]. Therefore, our knowledge of biomass allocation to roots lags behind that of its aboveground counterpart. A better understanding of the 


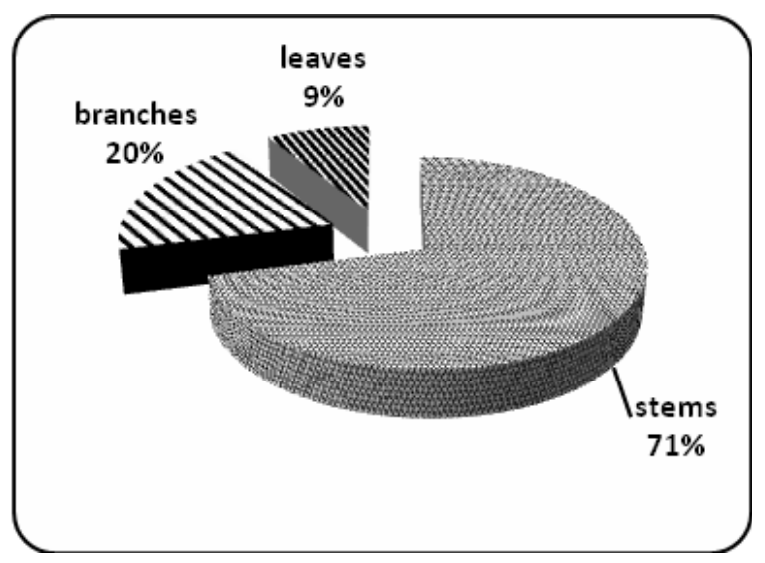

Figure 3. Biomass storage of different component stems, branches and leaves.

Table 2. Stand biomass C. siamea in different age classes

\begin{tabular}{|c|c|c|c|c|c|c|}
\hline \multirow{2}{*}{$\begin{array}{l}\text { Age } \\
\text { Class } \\
\text { (year) }\end{array}$} & \multirow{2}{*}{$\begin{array}{c}\text { Volume } \\
\mathrm{ha}^{-1} \\
\left(\mathrm{~m}^{3}\right)\end{array}$} & \multirow{2}{*}{$\begin{array}{c}\text { Bassal } \\
\text { Area } \\
\mathrm{ha}^{-1} \\
\left(\mathrm{~m}^{2}\right) \\
\end{array}$} & \multicolumn{3}{|c|}{ Biomass $\mathrm{Mg} \mathrm{ha}^{-1}$} & \multirow{2}{*}{ Total } \\
\hline & & & Stem & Branch & Leaf & \\
\hline $7^{*}$ & 172.36 & 28.85 & 69.26 & 37.28 & 29.36 & 136.39 \\
\hline $7 * *$ & 110.43 & 21.27 & 55.22 & 30.17 & 22.83 & 108.56 \\
\hline $5 * *$ & 82.21 & 16.99 & 46.40 & 25.33 & 18.59 & 90.32 \\
\hline $3 * *$ & 49.50 & 12.06 & 36.22 & 19.97 & 13.76 & 69.95 \\
\hline
\end{tabular}

$*=$ not mined $* *=$ mined

allocation of forest biomass, and the factors that regulate it, is needed for many applications including assessing change in forest structure, biogeochemical cycles, and various aspects of global change [18].

Root biomass data capture is the difficult part and did not have as good accuracy owned other vegetation components. Excavation around the roots is almost impossible to do, as well as sorting the roots are fine individually without mixed with the roots of other trees around it. Since it is difficult to take a sample, the approach is often used by using the ratio of root and stem (root to shoot ratio). In essence this is the ratio of the root stem expansion factor as BEF, in this case the ratio of the root stem copies data from unit to unit stands stands as well. The ratio is the ratio of the root stem / root biomass ratio between the biomass on the surface. Equation to obtain estimates of root biomass (root biomass density) among others, is an equation developed by [19].

$$
\mathrm{RBD}=\exp (-1.0587+0.8836 \times \ln \mathrm{AGB})
$$

$$
\begin{gathered}
\mathrm{RBD}=\text { root biomass density }\left(\mathrm{Mg} \mathrm{ha}^{-1}\right), \mathrm{AGB}=\text { Above } \\
\text { Ground Biomass }\left(\mathrm{Mg} \mathrm{ha}^{-1}\right) .
\end{gathered}
$$

Root biomass estimates are based on total AGB are presented in Table 3, the table contains data total AGB, root biomass and total tree biomass for each type of stand overall and each age class, and biomass in areas not mined and mined areas.

\subsection{Carbon Content and Absorption of $\mathrm{CO}_{2}$}

Forests play a role in improving the absorption of $\mathrm{CO}_{2}$ in which with the help of sunlight and water from the soil, vegetation chlorophyll to absorb $\mathrm{CO}_{2}$ from the atmosphere through photosynthesis. Result of photosynthesis, among others, are stored in the form of biomass that makes vegetation grow bigger or higher.

This growth will continue until the vegetation is physiologically stop growing or harvested. In general forest net growth (especially of trees were growth phase) were able to absorb more $\mathrm{CO}_{2}$, while the mature forest with a small growth just store carbon stock but cannot absorb excessive $\mathrm{CO}_{2}$ [20]. With the existence of the forest, the number of carbon $(\mathrm{C})$ stored the more and longer.

Therefore, planting vegetation on empty land or rehabilitate degraded forests will help to absorb the excess $\mathrm{CO}_{2}$ in the atmosphere.

By using allometric equation of the relationship between the diameter at breast height and total biomass, total carbon is derived from the value of biomass, shown in Table 4 . Table 4 is obtained by using the approach proposed earlier [21] in which the carbon content of forests constitute $50 \%$ of the forest biomass $[22,23]$. Carbon content for each tree

Table 3. Root biomass and total tree biomass $C$. siamea

\begin{tabular}{ccccccc}
\hline \multirow{2}{*}{$\begin{array}{c}\text { Age } \\
\text { (years) }\end{array}$} & \multicolumn{6}{c}{ Biomass $\left(\mathrm{Mg} \mathrm{ha}^{-1}\right)$} \\
\hline $7^{*}$ & 69.26 & 37.28 & 29.36 & 136.39 & 26.70 & 163.09 \\
$7^{* *}$ & 55.22 & 30.17 & 22.83 & 108.56 & 21.82 & 130.38 \\
$5^{* *}$ & 46.40 & 25.33 & 18.59 & 90.32 & 18.55 & 108.87 \\
$3^{* *}$ & 36.22 & 19.97 & 13.76 & 69.95 & 14.80 & 84.75 \\
\hline$*$ = not mined; ** = mined; & AGB $=$ Above Ground Biomass
\end{tabular}


Table 4. Total carbon sequestrationby C. siamea. results of revegetation

\begin{tabular}{|c|c|c|c|c|c|c|}
\hline \multirow{2}{*}{$\begin{array}{c}\text { Stand } \\
\text { Class } \\
\text { Age }\end{array}$} & \multicolumn{3}{|c|}{ Biomass } & \multicolumn{3}{|c|}{$\mathrm{Co}_{2}$ Absorption } \\
\hline & AGB & Root & Total & AGB & Root & Total \\
\hline & \multicolumn{6}{|c|}{$\mathrm{Mg} \mathrm{ha}^{-1}$} \\
\hline $7 *$ & 136.39 & 26.70 & 163.09 & 68.19 & 13.35 & 81.54 \\
\hline $7 * *$ & 108.56 & 21.82 & 130.38 & 54.28 & 10.91 & 65.19 \\
\hline $5 * *$ & 90.32 & 18.55 & 108.87 & 45.16 & 9.27 & 54.43 \\
\hline $3 * *$ & 69.95 & 14.80 & 84.75 & 34.98 & 7.40 & 42.38 \\
\hline
\end{tabular}

$*=$ not mined $* *=$ mined AGB $=$ Above Ground Biomass

component and total $\mathrm{CO}_{2}$ absorp by plants of each type are presented in Table 4.

Table 4 shows an increase in carbon sequestration as the increasing stand age. The potential of plantations to absorb $\mathrm{CO}_{2}$ from the atmosphere varies according to the species, its age and stand density. $\mathrm{CO}_{2}$ uptake by the stand could be increased if the silvicultural treatments applied in the area of mined revegetation. Many potential silvicultural treatments might be used to change, accelerate change, or maintain tree and stand conditions. Those that are typically used to foster improved tree growing conditions and or improved growth and yield include: choice of species and site,site preparation, planting, spacing, weeding and cleaning, thinning, pruning, fertilization, logging slash distribution.

\section{Conclusion}

1. Diameter of stands is an accurate estimator in formulating of allometric equations for estimating stem volume and biomass of C. siamea forest in East Kalimantan. Allometric equations in this study can be used to estimate stem volume and biomass stands of the Siamea, without having to cut down trees (destructive).

2. Carbon sequestration rates vary by tree species, soil type, regional climate, topography and management practice. The combination of treatments used in a silvicultural system can have large impact on growth and future yields
3. One of the functions of forests is controlling the climate by absorbing $\mathrm{CO}_{2}$ from the atmosphere and stores it in the form of organic matter in plant biomass. Forests are important in the restoration of degraded fragile ecosystems of used coal mining area.

\section{Acknowledgement}

I would like to express my appreciation to the reviewers for their constructive comments on the manuscript. I also are very grateful to Mrs. SitiNurmala and Mr. Arifien. This research was supported by the MSA Coal Mining Company, East Kalimantan, Indonesia.

\section{References}

1. Available from:http://www.ukessays.com/essays/environ mental-sciences/analysing-carbon-dioxide-sequestration-environmental-sciences-essay.php\#ixzz2ZfvFktQu

2. NRC (2010). Advancing the Science of Climate Change, National Research Council, The National Academies Press, Washington, DC, USA.

3. Available from: http://www.greatergood.org/gtgm-PlantTreesSequesterCarbon-32652.html.

4. Canadell J G, and Raupach M R (2008). Managing forests for climate change, Science (AAAS), vol 320(5882), 1456-1457.

5. Available from: http://www.effects-of-defo-restation.com/ reforestation.php

6. Forestry/Fuelwood Research and Development Project (F/FRED) (1994). Growing Multipurpose Trees on Small Farms, Module 9: Species Fact Sheets, $2^{\text {nd }}$ Edn., Bangkok, Thailand: Winrock Intemational, $127 \mathrm{p}$.

7. Available from: http://www.nanagarden.com/senna_ siamea\%5E1-11.html

8. Available from: http://eatingasia.typepad.com/ eatingasia/2005/10/gaeng_ki_lek_on.html

9. Available from: http://www.worldagroforestrycentre. org/sea/products/afdbases/af/asp/ Species Info.asp? $\mathrm{SpID}=461$

10. Available from: http://www.winrock.org/fnrm/factnet/ factpub/FACTSH/S_siamea.html

11. Sadeli I (2012). The Impact of revegetation on microclimate in coal mining areas in east kalimantan, Journal of Environment and Earth Science, vol 2, No. 11.

12. Available from: http://en.wikipedia.org/wiki/Biomass_ (ecology).

13. Skousen J, and Zipper C E (2012). Revegetation species and practices, Virginia Cooperative Extension (VCE) publication, 460-122. 
14. Peng C (1999). Growth and yield models for unevenaged stands:past, present and future, Forest Ecology and Management, vol 132 (2-3) 259-279.

15. Ilyas S (2011). Pendugaan Biomassa Pada Tegakan Hasil Revegetasi Lahan Bekas Tambang Batubara Studi Kasus Tanaman Johar (Cassia siamea, Lamk.), di PT. Multi Sarana Avindo Kalimantan Timur, Mulawarman Scientifie, vol 10, No. 1, 28-38.

16. Chave J, Condit R et al. (2004). Error propagation and scaling for tropical forest biomass estimates, Philosophical Transactions, The Royal Society Lond. B, vol 359, No. 1443, 409-420.

17. Cairnsá M A, Brown S et al. (1997). Root biomass allocation in the world's upland forests, Oecologia, vol 111(1), 1-11.

18. Brown F P, Pietra S A D et al. (1993) The Mathematics of Machine Translation: Parameter Estimation, Computational Linguistics, vol 19(2), 263-312.
19. Sutaryo D (2009). Penghitungan Biomassa Sebuah Pengantar Untuk Studi Karbon Dan Perdagangan Karbon, Wetlands International Indonesia Programme, Bogor, 5-15.

20. Kyrklund B (1990). The potential of forests and forest industry in reducing excess atmospheric carbon dioxide, Unasylva 163, vol 41, 12-14.

21. JIFPRO (2000). Feasibility study on local community oriented afforestation project for $\mathrm{CO}_{2}$ sequestration in Lombok Island, Indonesia.

22. Murdiyarso D, Rosalina U et.al. (2004). Pendugaan Cadangan Karbonpada Lahan Gambut, Proyek Climate Change, Forests and Peatlands in Indonesia. Wetlands International-Indonesia Programme dan Wildlife Habitat Canada. Bogor. Indonesia, 6-9.

23. West P W (2009). Tree and Forest Mensurement, SpringerVerlag, Berlin, Heidelberg, 47-63. 